\title{
MAXIMUM POST-GLACIAL MARINE SUBMERGENCE IN NORTHERN MELVILLE PENINSULA*
}

\author{
Victor W. Sim
}

\section{Introduction}

$\mathbf{L}$ ITTLE quantitative work has so far been done to determine the limits of marine submergence in arctic Canada. Until the last decade scattered altitudes obtained by early travellers were all that was available for large areas. In 1947, however, Washburn (1947, p. 61 ff.) collected all available information for the western Arctic and by combining it with his own observations presented the first unified account of arctic regional uplift. Since then the work of Bird has been noteworthy in the central and eastern Arctic. His studies in Southampton Island (1953), Bathurst Inlet (1955), and in the central Arctic as a whole (1954) have been particularly valuable. The present paper, based on observations made during the field seasons of 1957 and 1958, provides similar information for the northern part of Melville Peninsula, N.W.T. (Fig. 1).

Most contemporary geophysicists subscribe to the theory that a continental ice mass exceeding a certain minimum size in area and thickness will depress the crust of the earth by elastic compression and plastic deformation. When the weight of the ice is removed with deglaciation the crust will rebound nearly to its former position. Both Daly (1934, p. 135) and Gutenberg (1941, p. 752) considered that the amount of elastic compression was considerable. The former estimated it at 525 feet and the latter at $\mathbf{3 3 0}$ feet in North America. Mercer, however, has pointed out that the recovery from elastic compression takes place "if not theoretically instantaneously, actually as fast as the load is increased or decreased" (1954, p. 73). Gutenberg states $(1941$, p. 752$)$ : "fortunately we can disregard the elastic part of the uplift if we restrict ourselves to the time after the ice had disappeared. The movement, due to 'elastic afterworking' during the later period of the uplift was relatively small and may be included in the plastic uplift". Guilcher $(1958$, p. 46) in his discussion of glacial isostasy makes no mention of elastic compression, attributing the depression entirely to plastic deformation by "the slow flow of viscous material toward the periphery of the areas affected to re-establish an equilibrium".

*Published by permission of the Director, Geographical Branch, Department of Mines and Technical Surveys, Ottawa, Ontario, Canada. 
Since Melville Peninsula has probably not yet completely recovered from the weight of the recently melted ice cover, it is impossible to determine accurately the total crustal depression. Flint (1957, p. 242) has, however, expressed the opinion that crustal depression under an ice sheet should be roughly equivalent to one third of the total thickness of the ice. According to Daly $(1938$, p. 182$)$ an ice cap must have a minimum thickness of 3300 feet and a minimum diameter of 300 miles before it will depress the crust at all. Since Melville Peninsula and Foxe Basin have undoubtedly been depressed and since the Pleistocene ice cap over Foxe Basin certainly exceeded the minimum figures, a crustal depression of at least 1100 feet seems probable. The amount of uplift in the peninsula to date has been approximately 450 feet (pp. 189-92). Assuming that crustal depression is a completely reversible process the crust should rise another 650 feet before equilibrium will have been re-established. This figure is in the same range as the amount of uplift still to be expected in the Hudson Bay region (Gutenberg, 1941, p. 766).

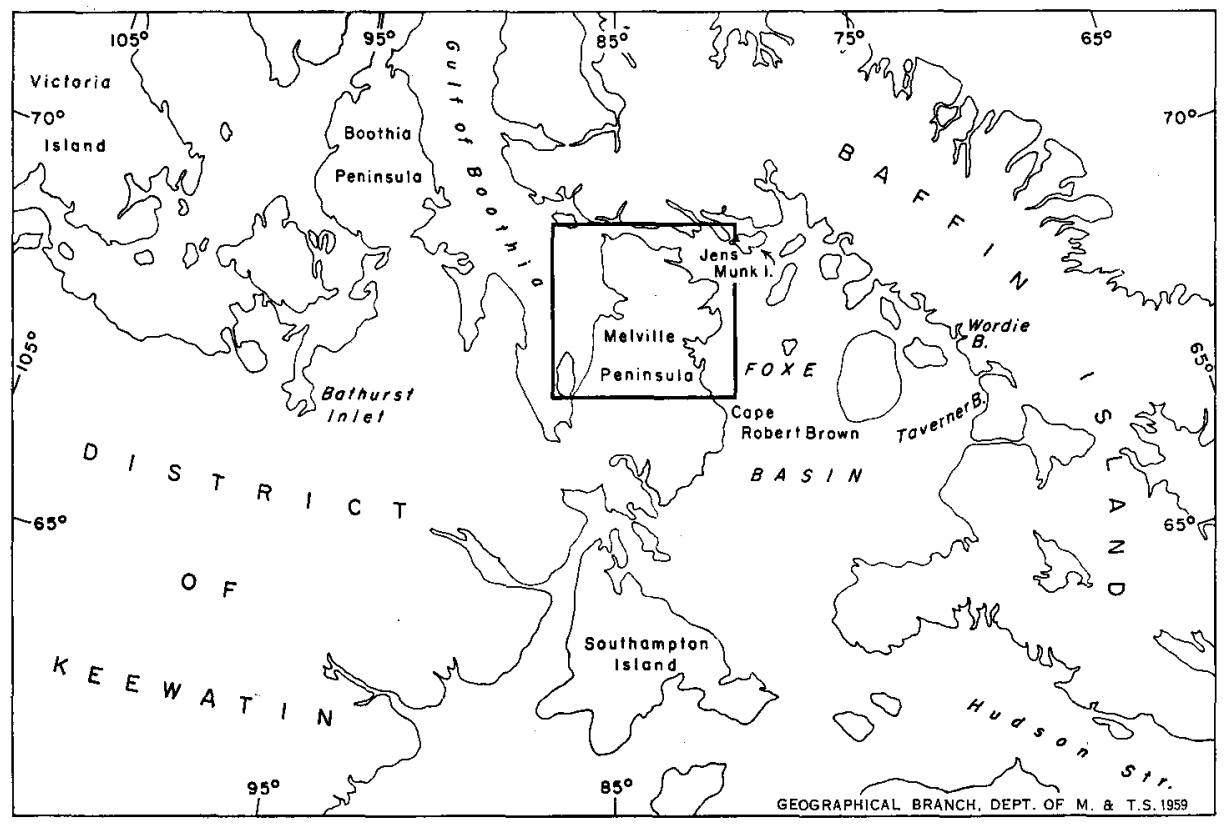

Fig. 1. Location map of Melville Peninsula.

Tide gauge records at Churchill, Manitoba (Gutenberg, 1941, p. 747) indicate that the shores of Hudson Bay are rising at a rate of 3 to 6 feet per century. Blackadar (1958, p. 164) using Meldgaard's archaeological data has recently determined a possible rise of 4.5 feet per century at Igloolik. The relatively shallow Foxe Basin-nowhere north of Cape Robert Brown do depths exceed 50 fathoms - may therefore be expected 
to become a broad flat plain drained by a major south-flowing stream in 6000 to 7000 years. Even at that time emergence will not be complete.

Soon after the ice cover over Melville Peninsula started to melt, the land began to rise. Some movement almost certainly took place while ice still lay over the peninsula and Foxe Basin. This early rise could leave no record, however, until the ice margin had retreated sufficiently to allow sea water to inundate the land and start forming strandlines. Flint (1957, p. 244) states: "as there are no means of measuring the amount of this early recovery, the value of total measured recovery is a minimum and total actual recovery was greater than this by an unknown amount". Moreover, the return to the ocean basins of water that had been abstracted during glaciation to form the ice caps caused a eustatic rise in sea-level. The quantity of water released by this process is estimated to have been sufficient to raise sea-level by amounts ranging from 275 to 390 feet (Flint, 1957, p. 260). Most of this rise had however taken place before isostatic recovery began in the area of Melville Peninsula. Since the figure for maximum submergence can only be related to the contemporary sea-level it must be remembered that the actual amount of recovery is too small by the amount of the eustatic rise in sea-level plus the amount of the early and unrecorded isostatic rise. There seems to be no way to measure either of these quantities.

\section{Determining the limits of marine submergence}

For Melville Peninsula a cursory examination of the air photographs of the eastern area is sufficient to indicate that the land has been submerged. Rows of well-developed parallel strand-lines rise inland to the westward across the eastern lowland. In the field the presence of unbroken marine shells on the ground at an altitude exceeding 200 feet also indicates submergence. Finally, former Eskimo camps, normally built near sea-level, are often found at altitudes considerably above this. Boulder tent rings, meat caches, whale and walrus skeletons, and occasional artifacts have been found at heights approaching 200 feet.

In determining the actual limits of post-glacial marine submergence the following four main criteria were used: (1) the highest altitude at which marine shells occur, (2) the highest altitude at which strand-lines are preserved, (3) the lowest altitude at which undisturbed ground moraines can be recognized, (4) the lowest altitude at which perched boulders are found.

\section{Marine shells}

Marine shells are common in raised deposits on the gently shelving east coast of the peninsula. They occur less frequently on the more rugged west coast where the conditions near the shore of a high-level sea did not provide a suitable environment for them. Wherever they are found unbroken and in considerable numbers, however, they may be taken to indicate submergence. The highest altitude at which shells are found is 
generally considered to mark the marine limit. However, many of the species found above sea-level today still live in coastal waters in the Arctic and it is known that at present they find their most favourable environment at a considerable depth below sea-level. Thus the altitude of the highest shells can only be taken as a minimum figure for the marine limit.

The collections of marine shells made during the summers of 1957 and 1958 were examined by Dr. F. J. E. Wagner of the Stratigraphic Palaeontology Section, Geological Survey of Canada. The species identified have been recorded in G.S.C. Report No. PL 6/57/58.

Of the several classes of mollusc that are known to occur above present sea-level in the Arctic, the pelecypods are most common. Three species were especially numerous in Melville Peninsula. Hiatella arctica Linné (= Saxicava arctica) was frequently found. This species has been cited by MacGinitie $(1955$, p. 174$)$ as the most abundant bivalve in the coastal waters at Point Barrow, Alaska, where it is most numerous at depths below 110 feet. It has a very wide ecological tolerance, having been observed in Alaska attached to boulders at a depth of only a few feet near the shore. This wide range may explain why this shell was frequently the highest species found in any locality. It was noted near the summits of several of the islands in Garry Bay at altitudes over 300 feet and was found at similar altitudes in the hills north and south of the Kingora River.

Macoma calcarea Guelin, the second most common species at Point Barrow (MacGinitie, 1955, p. 174), was taken there at depths averaging 70 feet. It was less common in Melville Peninsula but was found, often with the shell still hinged, in recently emerged stratified sands.

The only other mollusc that deserves mention is Mya truncata Linné. This species, not common at Point Barrow, occurred widely in Melville Peninsula. It was found in Alaska at depths ranging from 122 feet to 477 feet. South of Amherst Island on the Melville mainland it was found at an altitude of over 400 feet near the limit of submergence.

Other pelecypods that were noted at altitudes above present sealevel include Astarte borealis Schumacher, Clinocardium ciliatum Fabricius and Serripes groenlandicus Bruguière. All these species were found by MacGinitie (1955, p. 173) to be most common at depths exceeding 80 feet. Gastropods occur infrequently in raised marine deposits. One species, Colus sp., did occur in considerable numbers at the mouth of Hall River.

Two of the three principal molluscs found in Melville Peninsula live normally at depths exceeding 70 feet. The less common species prefer depths greater than 80 feet. Only Hiatella arctica can be expected to occur in shallow water and even this species has a marked preference for deeper water. Any particular shell of this species found above present sea-level probably lived within the normal range for the species. It is not surprising, therefore, that the use of marine shells to determine the limit of marine submergence commonly gives a result considerably lower than that yielded by other criteria. In effect the highest marine shell may mark an altitude at least 70 feet, possibly 100 feet, lower than the actual marine limit. 
It may be argued that the highest marine shells are those that have been washed up on shore during storms when the sea stood at its maximum elevation. Since the natural environment of the molluses is considerably below the limit of normal wave action it is probable that the number of shells deposited in this way was small. Those that were deposited would be quickly destroyed by subsequent wave action or by weathering in their exposed positions. Shells, moreover, are extremely rare in the tidal zone or on storm ridges along the modern shore of the peninsula.

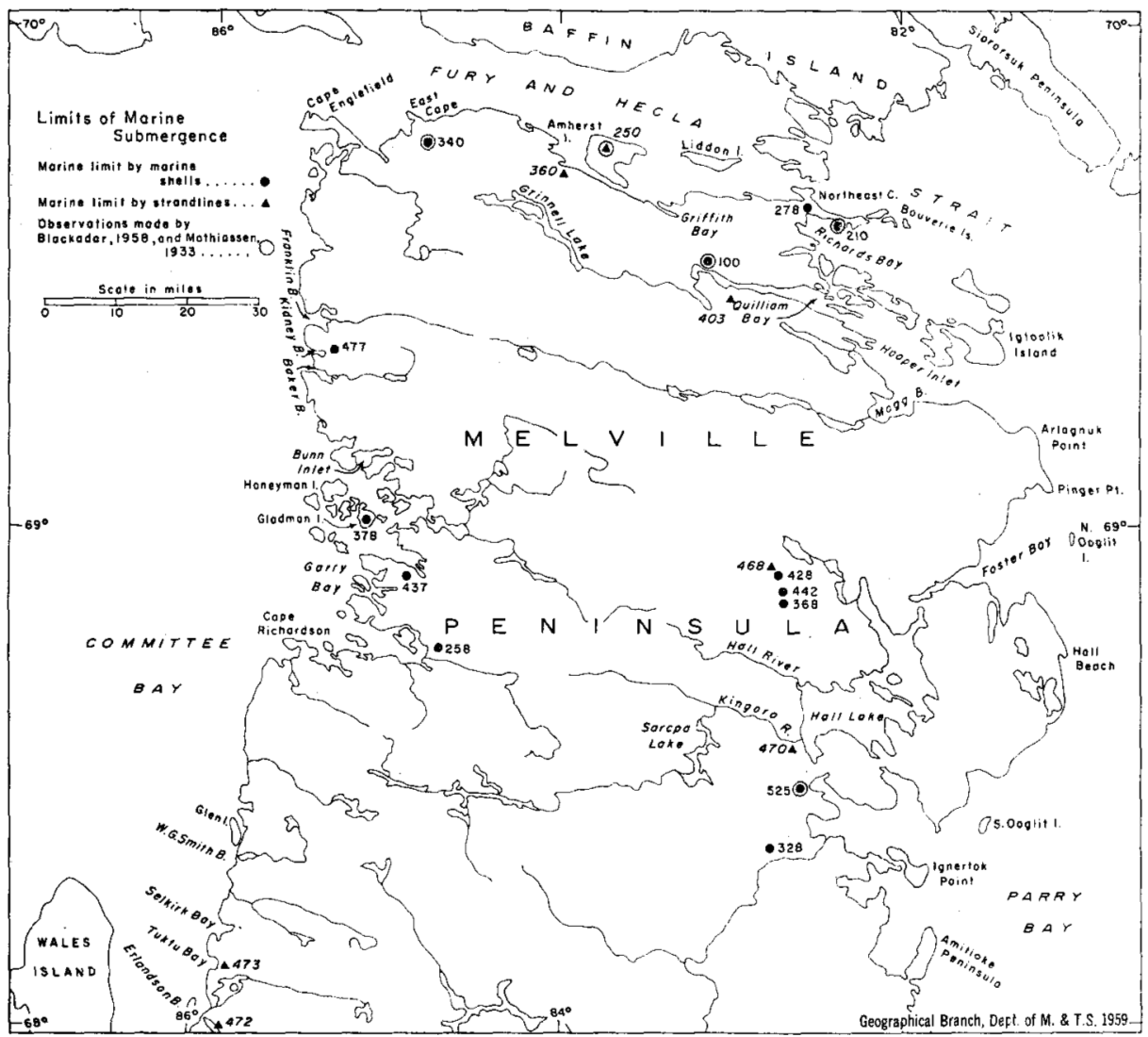

Fig. 2. Map showing locations and altitudes of marine shells and strand-lines.

In general, shells were found to have only limited value in determining the marine limit. On the west coast where the land rises steeply shells are at first numerous, but decrease rapidly in number with increasing altitude and often could not be found above 200 feet. Even on the gently rising east coast diligent search was required to find shells at higher altitudes. The highest marine shell discovered was at an elevation of 477 feet. A mean value for the limit of submergence determined by this method is 404 feet. Locations and altitudes of the highest shells are shown on Fig. 2. 


\section{Strand-lines}

Raised strand-lines are found widely distributed in all coastal areas of Melville Peninsula, but are most numerous on the eastern limestone lowland. They are less common on the north and west coasts, but are well developed on Wales Island and on the headlands at the mouth of Franklin and Baker Bays. Here and there on steeply rising Precambrian coasts uninterrupted series of bayhead cobble beaches rise in step-like arrangement for short distances above present sea-level. In these locations no major interruptions are visible in the closely spaced strand-lines and this suggests continuous emergence.

Features resembling strand-lines found at high levels must be interpreted with caution as indicators of the marine limit because as Bird points out $(1953$, p. 21$)$ they may in fact be lateral moraines, river terraces, or other fluvio-glacial forms. For example, pockets of water-worn pebbles and sand found at considerable altitudes may be of marine origin or they may equally well be glacial stream deposits.

Strand-lines are found most often at altitudes close to present sealevel. Their number and state of preservation decrease with increasing altitude. The higher and older strand-lines have been exposed longer to subaerial erosion than lower ones and have been largely destroyed. For this reason the criterion of raised strand-lines was seldom of value in determining the limit of marine submergence. However, where present, strand-lines yielded results that varied little from those deduced from undisturbed ground moraine and perched boulders. The mean altitude for the marine limit in northern Melville Peninsula determined by strand-lines is 440 feet. Altitudes for the limit determined in this way have been plotted on Fig. 2.

\section{Undisturbed ground moraine}

The lowest limit of undisturbed ground moraine may be taken to mark the highest level of the sea. The method of using this criterion first suggested by Daly $(1902$, p. 258$)$, has been described by Bird $(1953$, p. 21$)$ and applied by him on Southampton Island. For Melville Peninsula it may be summarized as follows: after the melting of the ice sheet the land surface was covered with a veneer of bouldery ground moraine of variable composition. In some areas this moraine consists of a scattered layer of large boulders on a bare rock surface. Elsewhere it is a blanket of bouldery till several feet thick. Whatever its composition this material could not escape some degree of alteration by wave action in the post-glacial sea. The limit of this wave action is often visible on the land surface and its altitude can be determined.

Where the ground moraine consists of a scattered cover of boulders on a sloping Precambrian surface the area below the marine limit is often swept completely bare of boulders. Above this sharply defined region the boulders are undisturbed. Where the ground moraine is composed of glacial till the marine limit shows up equally well. In the material above the limit 


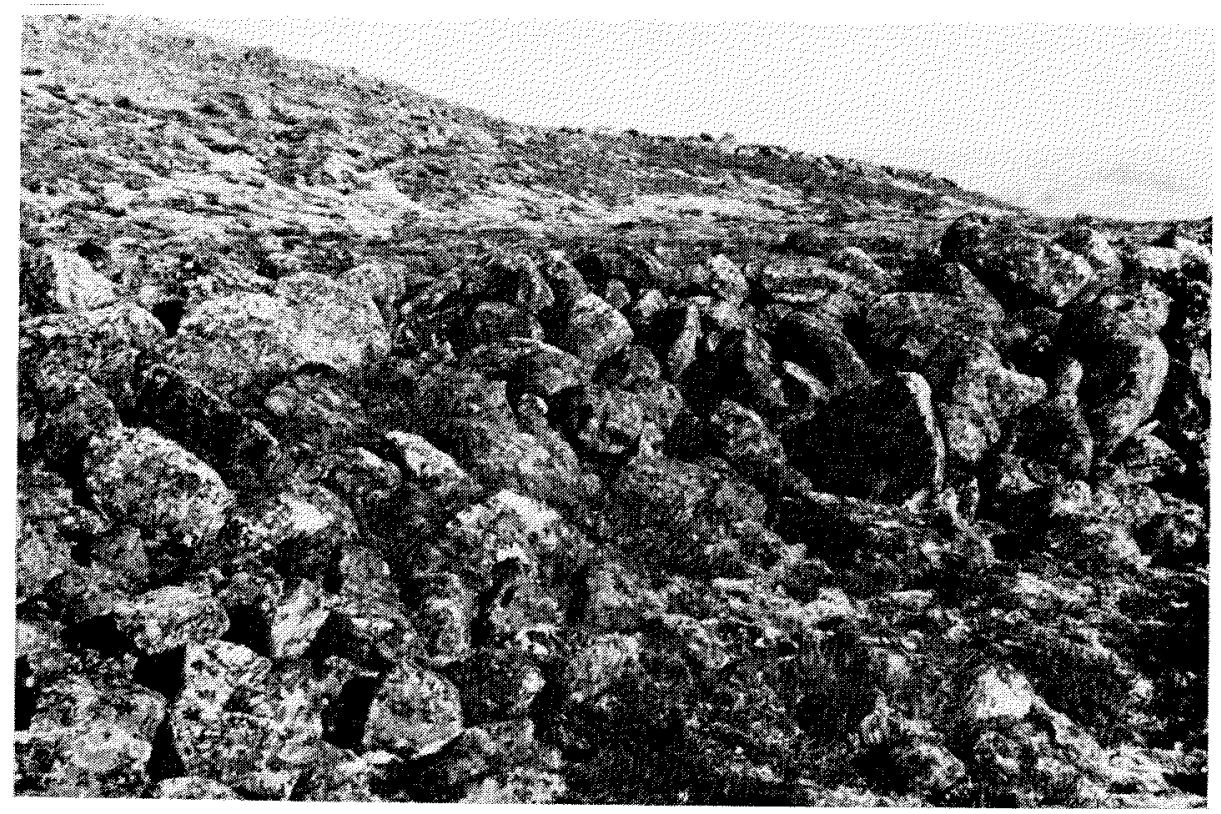

Fig. 3. Boulder bench at the limit of marine submergence near Erlandson Bay, west coast of Melville Peninsula. Undisturbed ground moraine may be noted on the slope rising behind the bench.

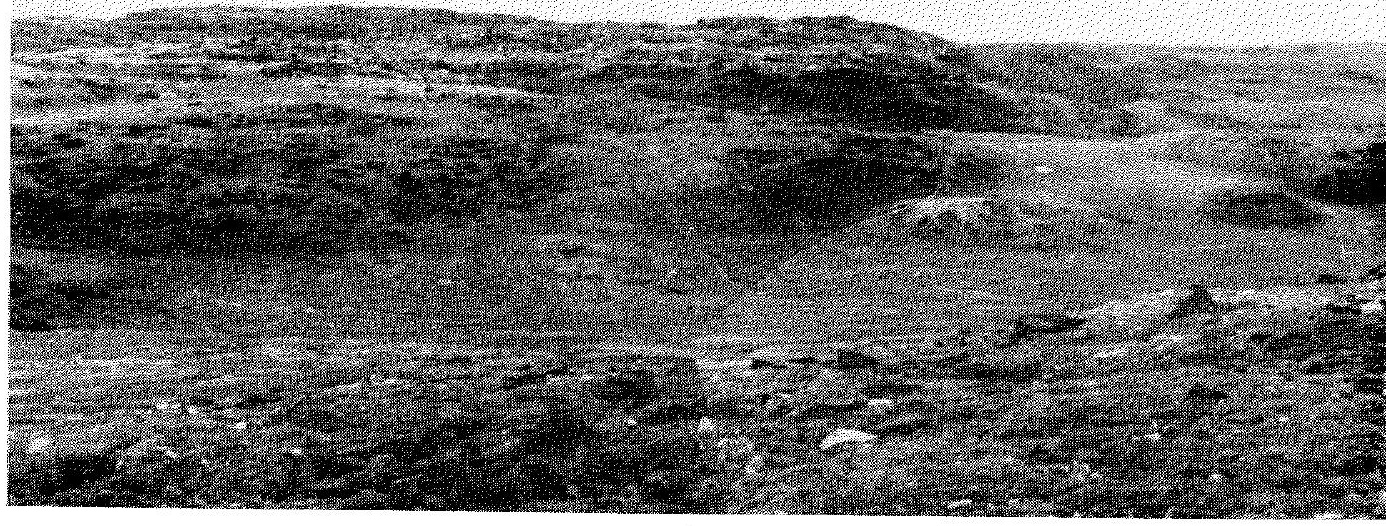

Fig. 4. Terrain in foreground and hilltop in left background are veneered with undisturbed ground the photograph and the terrain in the right background are below the limit of marine

there is an obviously heterogeneous mixture and the moraine has an "unsorted" appearance. Boulders often project with their long axes vertical 
to the surface of the ground. The ground surface is irregular and resembles that of a solifluction lobe. Below the marine limit, which may be marked by a slight break in the slope or by a pronounced bench (Fig. 3) the material is visibly different. Here it has a partly sorted, waterwashed look. Minor surface irregularities have been removed and the boulders are solidly embedded in the moraine. Furthermore, the vegetation of grasses, arctic willow, avens and purple saxifrage often forms a more complete ground cover.

The distinction between previously submerged and unsubmerged ground moraine can be clearly seen, moreover, in a more general view of the landscape. Below the marine limit the terrain has a smoothed and softly contoured appearance. Hill tops may be bare rock knobs whereas the shoulders of the hills are covered with partially sorted till. Slopes are smooth and gently concave and the area has a "neat" appearance. Above the marine limit the ground surface is littered with boulders and cobbles. Ridges and hills have a serrated, irregular skyline and the appearance is "untidy" (Fig. 4).

Using undisturbed ground moraine as an indicator was the most easily applied and most reliable criterion for determining the marine limit in northern Melville Peninsula. A mean value for the limit of submergence determined by this method is 466 feet. This value is a little more than

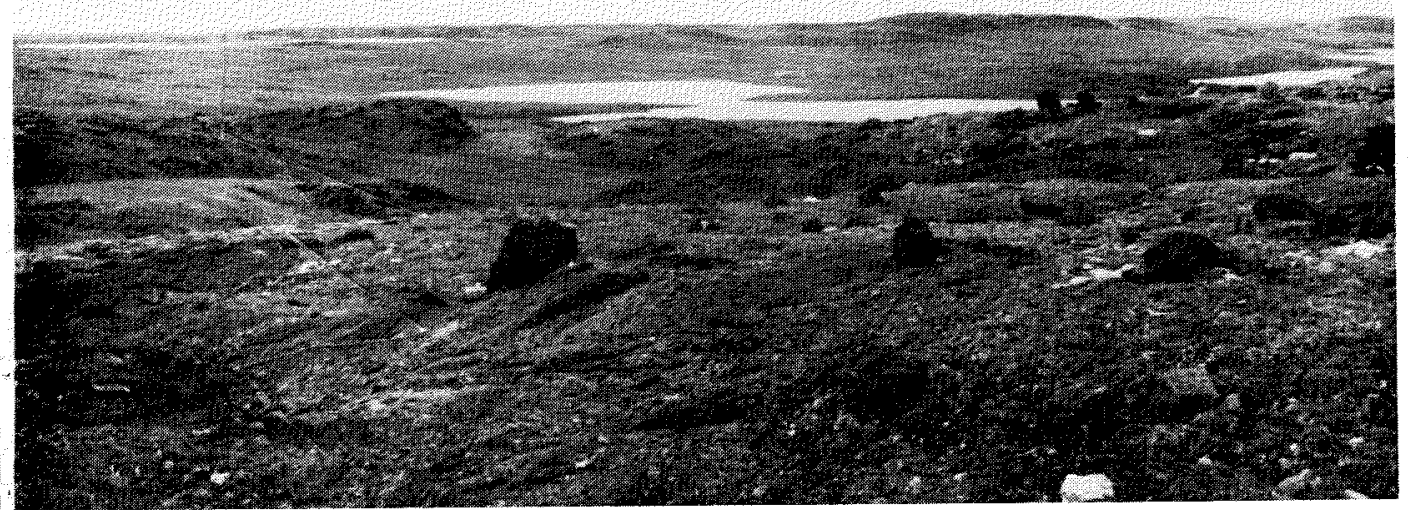

moraine above the limit of marine submergence. The depression running from left to right across submergence. View toward the east across the crystalline upland northwest of Hall Lake.

20 feet higher than the mean value indicated by the highest strand-lines. The values are plotted on Fig. 5 . 


\section{Perched boulders}

Perched boulders of large size resting on several smaller boulders are often so precariously balanced that they may be easily toppled over, Fig. 6 . They may originally have been deposited by random dumping of englacial debris during deglaciation. Since it is not probable that such boulders could survive wave action and ice push at the shores of a post-glacial sea their presence indicates an altitude above the marine limit.

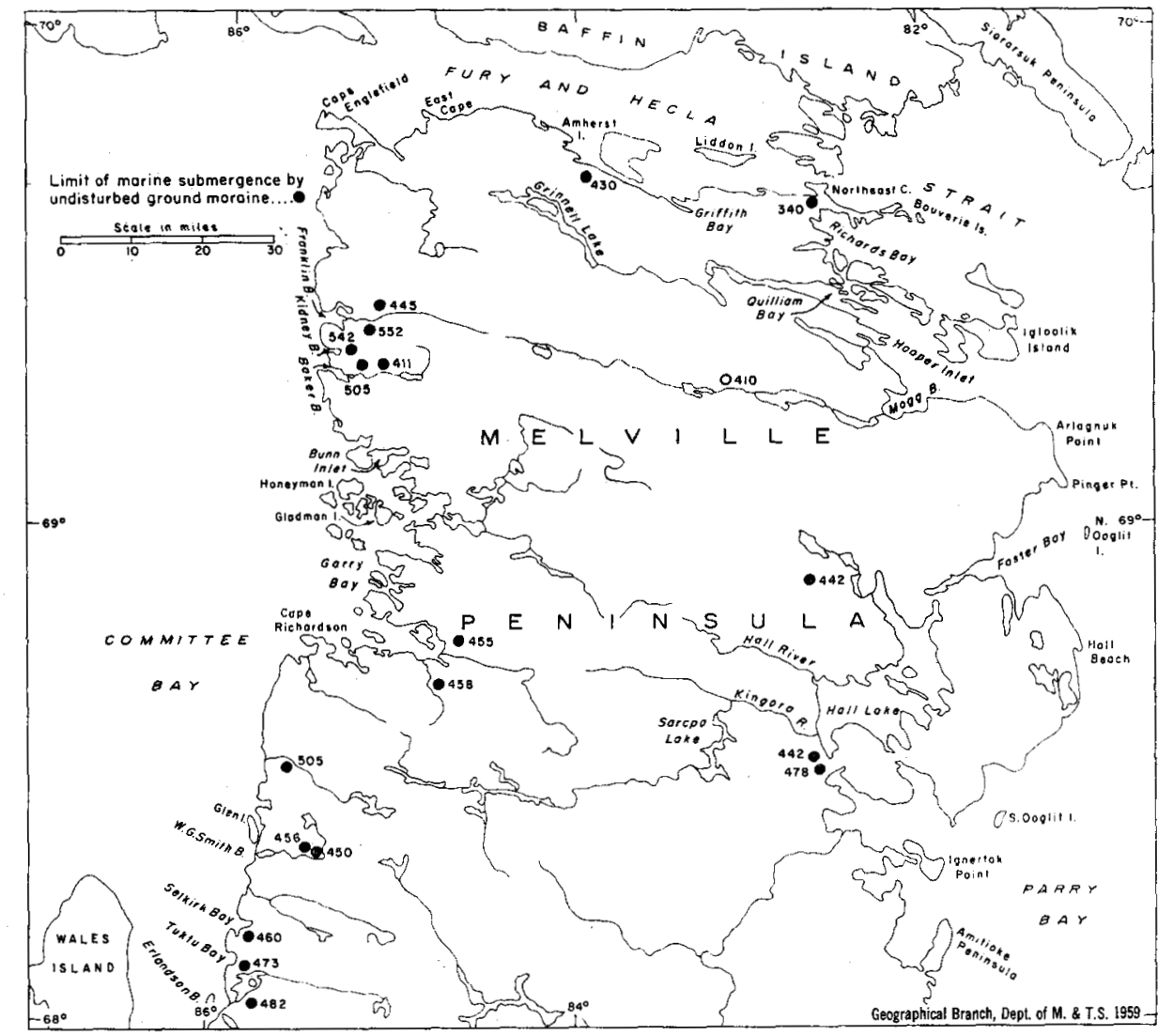

Fig. 5. Map showing locations and altitudes of undisturbed ground moraines.

Perched boulders must be interpreted with caution, however, since they may occasionally be seen at altitudes between sea-level and the marine limit. Thompson $(1954$, p. 173) suggests that rocks may be perched as the result of rockfalls or by rolling down snow banks to lodge on the boulders at the base of the slope. The writer has seen such perched blocks, however, and it seems that they can almost invariably be recognized for what they are. Others are less easy to explain. Several large perched boulders no 
more than 30 feet above sea-level were observed on a low saddle between two Precambrian knobs near the south entrance to Bunn Inlet in Garry Bay. Many other boulders of a similar size but not perched were scattered about on the surface nearby. It is suggested that they may have been rafted into the area on ice floes and dropped into position when the ice grounded and later melted on the saddle. If they were deposited slightly above sealevel they might possibly have survived until they were lifted out of danger by continued emergence of the land. Local conditions usually make it possible to distinguish between perched blocks that are true indicators of marine submergence and those that are of more recent origin.

Perched boulders, where they occur on open hillsides away from steep cliffs and in association with others at the same altitude may be safely interpreted as having been deposited above the marine limit. The altitudes of perched boulders are plotted on Fig. 7 and from these data a mean value of 454 feet is obtained for the limit of marine submergence.

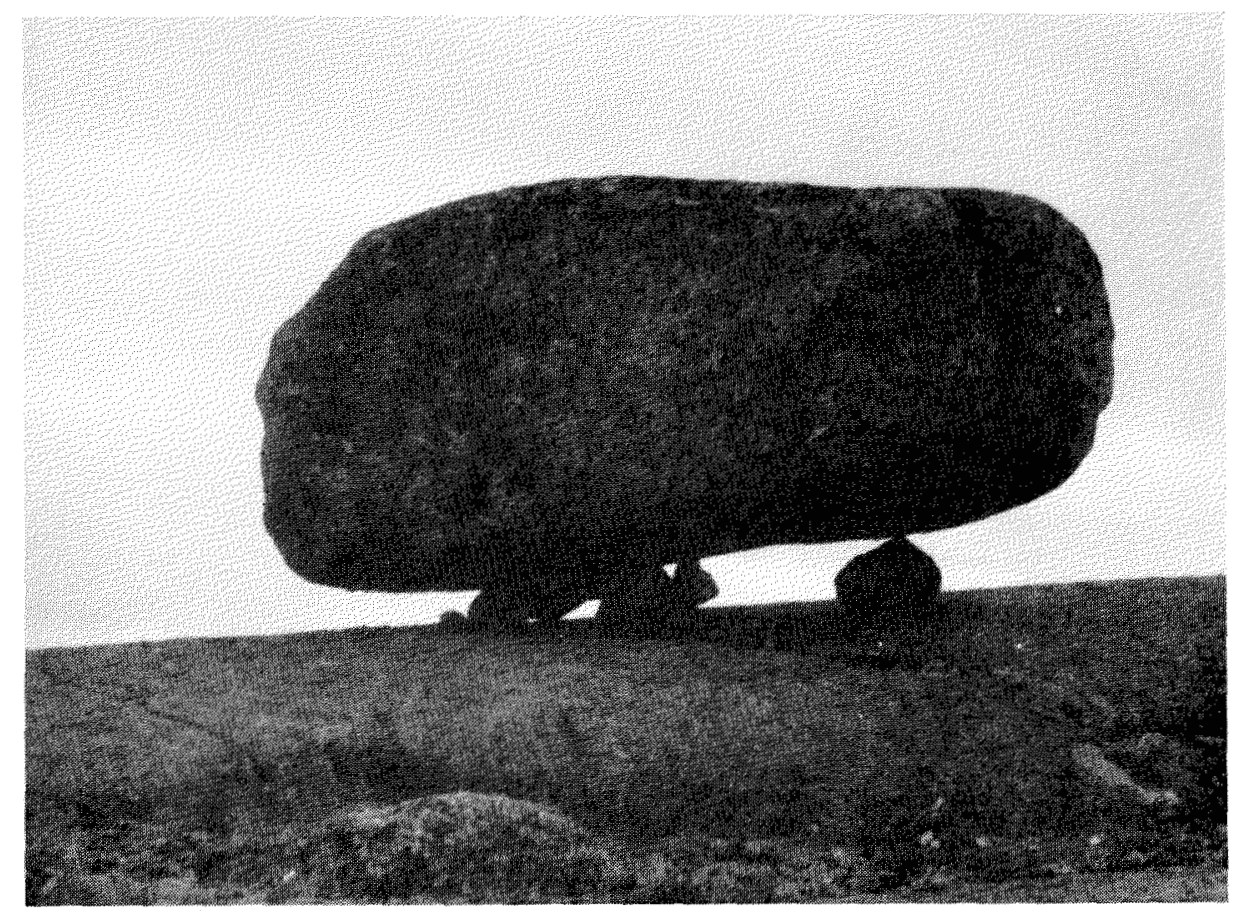

Fig. 6. Perched boulder above the limit of marine submergence.

\section{Foraminifera}

An attempt was made during the field seasons of 1957 and 1958 to determine the limit of submergence using foraminifera. Although the presence of marine microfossils in a sample of surface material may be taken 
as conclusive proof of submergence, this criterion suffers from the same disadvantage as does the use of larger shells, since foraminifera are also largely benthonic and their presence only indicates a minimum figure.

Samples of surface material that seemed likely to contain foraminifera were collected in the field. These were subsequently examined by the Section of Stratigraphic Palaeontology of the Geological Survey of Canada.

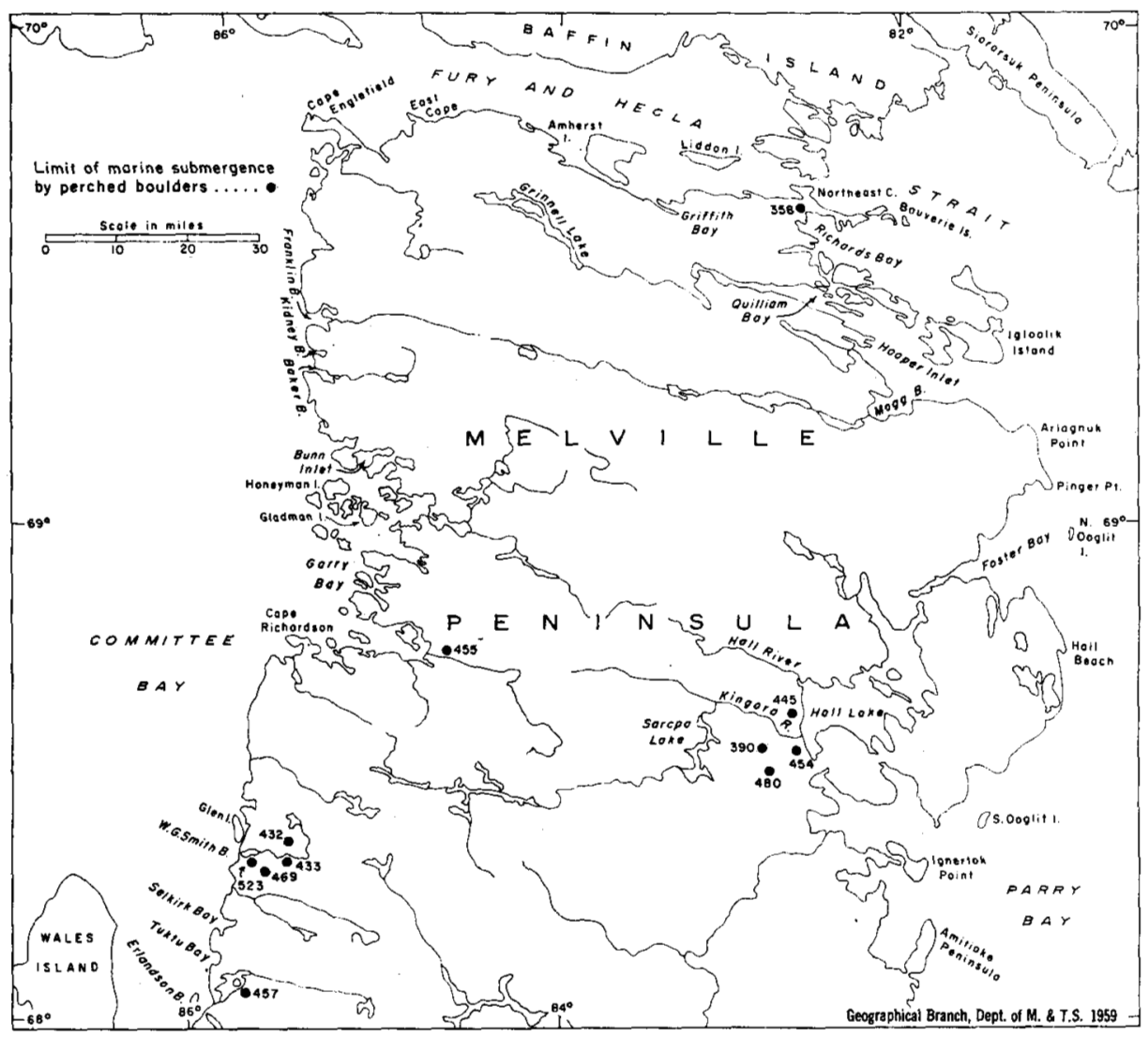

Fig. 7. Map showing locations and altitudes of perched boulders.

The most common species of microfossils discovered in the samples are listed in Table 1. The assemblage is very similar to that identified by Loeblich and Tappan (1953) from a collection made at Point Barrow, Alaska in the present offshore zone. An examination of the range table in their publication (1953, pp. 11-13) shows that with one or two exceptions all the common species from Melville Peninsula were taken at Point Barrow in depths exceeding 70 feet. Thus, even if these species were sampled in Melville Peninsula at the shoreward limit of their range, the actual marine limit, determined in this way, would still stand approximately 70 feet above 
the level at which the fossils were found. In addition, Loeblich and Tappen found several species, notably Dentalina ittai and Lagena opiopleura, only in the comparatively narrow depth range from 70 to 160 feet below the

Table 1. Common species of foraminifera found in surficial deposits below the limit of marine submergence on Melville Peninsula, 1957-8.

\begin{tabular}{lrr}
\hline \multicolumn{1}{c}{ Species } & $\begin{array}{c}\text { Depth Range for Point Barrow } \\
\text { (after Loeblich and Tappan 1953) }\end{array}$ \\
\hline Elphidium orbiculare Brady & $0-725 \mathrm{ft}$. & $0-223 \mathrm{~m}$. \\
Elphidium subarcticum Cushman & $>70 \mathrm{ft}$. & $>21 \mathrm{~m}$. \\
Elphidium frigidum Cushman & $>70 \mathrm{ft}$. & $>21 \mathrm{~m}$. \\
Buccella frigida Cushman & $70-442 \mathrm{ft}$. & $21-136 \mathrm{~m}$. \\
Buccella musitata Anderson & $0-725 \mathrm{ft}$. & $0-223 \mathrm{~m}$. \\
Oolina caudigera Meisner & $>70 \mathrm{ft}$. & $>21 \mathrm{~m}$. \\
Lagena gracillima Seguenza & $>70 \mathrm{ft}$. & $>21 \mathrm{~m}$. \\
Lagena semilineala Wright & $>70 \mathrm{ft}$. & $>21 \mathrm{~m}$. \\
Lagena opiopleura Loeblich and Tappan & $70-162 \mathrm{ft}$. & $21-50 \mathrm{~m}$. \\
Dentalina ittai Loeblich and Tappan & $70-162 \mathrm{ft}$. & $21-50 \mathrm{~m}$. \\
\hline
\end{tabular}

surface. Whereas small numbers of many foraminifera may occasionally be found near the shore, these two species that are common in raised deposits in Melville Peninsula are never found in the present day beach zone at Point Barrow. If the habitat requirements for these species have not changed in the past several thousand years, the highest shells of these species probably lie at an altitude at least 70 feet below the marine limit. Lack of familiarity with the method prevented the writer from making any final estimates of the limit of marine submergence using microfossils. It would seem to be a valuable method to be employed where very accurate minimum figures are to be determined for a small area. It is also an ideal method for determining whether clay and silt deposits are of lacustrine or marine origin.

\section{Summary of results}

Table 2 presents the limits of marine submergence as indicated by the four principal criteria. These four methods do not of course yield strictly comparable results. It was usual to find that marine shells gave the lowest figure. Strand-lines, undisturbed ground moraine, and perched boulders, in that order, gave increasingly higher results. The highest shell localities in any area ranged in altitude from 258 to 525 feet. High strand-lines varied from 360 to 473 feet. The lower altitude of both may be discounted. It merely indicates that either no strand-lines have survived above that altitude or that the coastal topography was not suitable for their formation. In the above ranges the four altitudes determined by Blackadar (1958, p. 156) in the vicinity of Fury and Hecla Strait have also been excluded. These altitudes are samples determined during the course of field traverses and do not necessarily indicate maximum occurrences. The mean altitude of the marine limit determined by shells is 404 feet and by raised beaches 440 feet. 
Undisturbed ground moraine and perched boulders were the most easily applied limiting criteria. The former ranged in value from 410 to 552 feet and the latter from 390 to 523 feet. The anomalous values that were obtained for both near Northeast Cape and are discussed below have been disregarded. The values give a maximum range of only 162 feet. The mean value for the limit of submergence as determined by undisturbed ground moraine is 466 feet. The value determined by perched boulders is 454 feet.

Anomalous results are indicated by the few altitudes obtained by the author in the northeast corner of the peninsula near Northeast Cape. Excluding the random altitudes determined by Blackadar as not being maximum values, Table 2 shows that the altitudes determined by marine shells, undisturbed ground moraine, and perched boulders were 278, 340 and 358 feet respectively. These altitudes are more than 100 feet lower than the corresponding means for the rest of the peninsula. It is possible that this area was covered by a residual ice mass located in northern Foxe Basin until very late. There is some indication of "dead ice" landscape southwest of Quilliam Bay to support this suggestion. By the time this remnant ice finally melted and the sea inundated the area to form strandlines an isostatic recovery of 100 feet or more could already have taken place. This early recovery was not recorded on the land surface. Until many more data are available for the marine limit on Jens Munk Island and Baffin Island to the north this can be no more than conjecture.

In general the altitudes obtained in northern Melville Peninsula for the marine limit are considerably lower than those determined by Bird for Southampton Island. The limit, using the ground moraine method, in that area is about 600 feet (Bird, 1953, p. 24) whereas the limit by the same method on Melville Peninsula is only 466 feet. On an unpublished manuscript map on which isobases have been plotted using available data from Arctic Canada the contour pattern over Foxe Basin and Melville Peninsula suggests that this area was depressed by, and is now recovering from, the weight of an ice mass centred over Foxe Basin. The lower limits for maximum marine submergence in this area may be due to the presence of this ice until considerably later than the cover over Southampton Island. Because of the limitation of time and surveying technique it was impossible to determine whether the emerged strand-lines have been tilted.

An attempt has been made to show in Fig. 8 the coastal configuration of Melville Peninsula at the time of maximum extent of the postglacial sea. The western coastline did not differ greatly from its present shape. Since it was submerged to a depth of approximately 450 feet, arms of the sea extended in long estuaries 8 to 10 miles up the valleys of the major streams. The low headlands at the mouths of Franklin and Baker Bays were submerged as were the islands in Garry Bay, Wales Island and the adjacent coastal strip of Erlandson Bay. In Fury and Hecla Strait the Proterozoic lowland was submerged together with Amherst and Liddon Islands, Northeast Cape, and the Bouverie Islands. A small island persisted west of 
Table 2. Highest observed altitudes ${ }^{1}$ of post-glacial marine submergence in Melville Peninsula.

\begin{tabular}{|c|c|c|c|c|c|}
\hline \multicolumn{2}{|l|}{ Locality } & $\begin{array}{l}\text { Marine } \\
\text { shells }\end{array}$ & $\begin{array}{l}\text { Strand- } \\
\text { lines }\end{array}$ & $\begin{array}{l}\text { Ground } \\
\text { moraines }\end{array}$ & $\begin{array}{l}\text { Perched } \\
\text { boulders }\end{array}$ \\
\hline Franklin Bay, $69^{\circ} 25^{\prime}$ N. $85^{\circ} 10^{\prime}$ W. & \multirow[t]{2}{*}{ 1) } & . & · & $\begin{array}{l}445 \\
552\end{array}$ & $\cdot$ \\
\hline Kidney Bay, $69^{\circ} 22^{\prime}$ N. $85^{\circ} 15^{\prime} \mathrm{W}$. & & 477 & $\dot{.}$ & $\begin{array}{l}552 \\
542\end{array}$ & $\dot{.}$ \\
\hline Baker Bay, $69^{\circ} 18^{\prime}$ N. $85^{\circ} 15^{\prime} W$. & 1) & & . & 411 & $\cdot$ \\
\hline \multicolumn{2}{|l|}{ Gladman Island (Garry Bay) } & 378 & $\dot{0}$ & $\cdot$ & \multirow{3}{*}{$4 \dot{55}$} \\
\hline \multirow{2}{*}{\multicolumn{2}{|c|}{$\begin{aligned} & \text { Garry Bay, } 68^{\circ} 56^{\prime} \text { N. } 84^{\circ} 54^{\prime} \mathrm{W} \\
& 68^{\circ} 45^{\prime} \mathrm{N} .84^{\circ} 40^{\prime} \mathrm{W} \\
& 68^{\circ} 43^{\prime} \text { N } 84^{\circ} 47^{\prime} \mathrm{W}\end{aligned}$}} & $\begin{array}{l}437 \\
258\end{array}$ & $\dot{.}$ & $4 \dot{5} 5$ & \\
\hline & & 200 & $\dot{.}$ & 458 & \\
\hline \multirow{5}{*}{ W. G. Smith Bay, near $68^{\circ} 22^{\prime}$ N. $85^{\circ} 36^{\prime}$ W. } & & . & . & 505 & \multirow{2}{*}{$\begin{array}{l}5 \dot{2} 3 \\
432\end{array}$} \\
\hline & 1) & $\cdot$ & . & $\cdot$ & \\
\hline & 3) & : & : & $4 \dot{5} 6$ & \multirow{3}{*}{$\begin{array}{c}432 \\
\cdot \\
4 \dot{3} 3 \\
469\end{array}$} \\
\hline & 4) & . & . & 450 & \\
\hline & 5) & $\cdot$ & $\cdot$ & $\cdot$ & \\
\hline \multirow{4}{*}{$\begin{array}{l}\text { Selkirk Bay, } 68^{\circ} 11^{\prime} \mathrm{N} .85^{\circ} 50^{\prime} \mathrm{W} . \\
\text { Tuktu Bay, } 68^{\circ} 08^{\prime} \text { N. } 85^{\circ} 50^{\prime} \mathrm{W} \text {. } \\
\text { Erlandson Bay }\end{array}$} & \multirow{4}{*}{$\begin{array}{l}\text { 1) } \\
\text { 3) }\end{array}$} & - & \multirow{2}{*}{$4 \dot{73}$} & $4 \dot{6} 0$ & \multirow{3}{*}{$4 \dot{5} 7$} \\
\hline & & . & & \multirow{2}{*}{$\begin{array}{l}473 \\
4 \dot{8} 2\end{array}$} & \\
\hline & & - & & & \\
\hline & & \multirow{2}{*}{$3 \dot{4} 0^{2}$} & \multirow[t]{2}{*}{$4 \dot{72}$} & \multirow{2}{*}{$:$} & \multirow{3}{*}{$:$} \\
\hline \multirow{2}{*}{\multicolumn{2}{|c|}{ Four miles southeast of East Cape }} & & & & \\
\hline \multirow{2}{*}{\multicolumn{2}{|c|}{$\begin{array}{l}\text { South shore of Fury and Hecla Strait, } \\
69^{\circ} 44^{\prime} \text { N. } 83^{\circ} 58^{\prime} \mathrm{W} \text {. } \\
\text { South of Ouilliam Bav, } 69^{\circ} 28^{\prime} \text { N. } 83^{\circ} 00^{\prime} \mathrm{W} \text {. }\end{array}$}} & . & $2 \dot{5} 0^{2}$ & . & \\
\hline & & . & $\begin{array}{l}360 \\
403^{3}\end{array}$ & 430 & \multirow{2}{*}{$\dot{0}$} \\
\hline $\begin{array}{l}\text { South of Quilliam Bay, } 69^{\circ} 28^{\prime} \mathrm{N} .83^{\circ} 00^{\prime} \mathrm{W} \text {. } \\
\text { Near unnamed river, } 69^{\circ} 18^{\prime} \mathrm{N} .85^{\circ} 10^{\prime} \mathrm{W} \text {. }\end{array}$ & & . & $403^{3}$ & 410 & \\
\hline Northwest of Hall Lake, $68^{\circ} 55^{\prime} \mathrm{N} .82^{\circ} 40^{\prime} \mathrm{W}$. & \multirow{2}{*}{$\begin{array}{l}\text { 1) } \\
\text { 3) }\end{array}$} & $\begin{array}{l}428 \\
442\end{array}$ & $4 \dot{6} 8$ & $4 \dot{4} 2$ & $\dot{0}$ \\
\hline \multirow{5}{*}{$\begin{array}{l}\text { Near mouth of Kingora River } \\
\text { West shore of Hall Lake, } 68^{\circ} 38^{\prime} \mathrm{N} .82^{\circ} 42^{\prime} \mathrm{W} \text {. } \\
\text { South of Kingora River }\end{array}$} & & & 470 & . & $4 \dot{5} 4$ \\
\hline & \multirow{5}{*}{$\begin{array}{l}\text { 1) } \\
\text { 2) } \\
\text { 4) }\end{array}$} & & & . & 445 \\
\hline & & . & . & in & 390 \\
\hline & & : & $\dot{.}$ & $\begin{array}{l}442 \\
478\end{array}$ & \\
\hline & & & & . & $4 \dot{80}$ \\
\hline $\begin{aligned} \text { Parry Bay, } 68^{\circ} 30^{\prime} \mathrm{N} .82^{\circ} 40^{\prime} \mathrm{W} & 68^{\circ} 22^{\prime} \mathrm{N} .82^{\circ} 50^{\prime} \mathrm{W}\end{aligned}$ & & $\begin{array}{l}525^{4} \\
328\end{array}$ & : & $\dot{.}$ & $\dot{0}$ \\
\hline & lous & & & & \\
\hline Five miles southwest of Northeast Cape & & 278 & . & 340 & 358 \\
\hline $\begin{array}{l}\text { Bouverie Islands } \\
\text { Quilliam Bay }\end{array}$ & & $\begin{array}{l}210^{2} \\
100^{2}\end{array}$ & : & : & \\
\hline $\begin{array}{l}\text { Range of values } \\
\text { area near Northeast } \text {. values for anomalous } \\
\text { Mean value (excl. values for anomalous area) }\end{array}$ & & $\begin{array}{c}258-525 \\
404\end{array}$ & $\begin{array}{c}360-473 \\
440\end{array}$ & $\begin{array}{l}410-552 \\
466\end{array}$ & $\underset{454}{390-523}$ \\
\hline
\end{tabular}

1All altitudes are in feet above sea-level. They were obtained with a Paulin surveying altimeter and have been corrected for pressure changes. All observations by the author unless attributed otherwise.

2Observations by Blackadar and not necessarily maximum altitudes for the areas.

3Doubtful strandline.

4After Mathiassen 1933.

5 Observations by Blackadar have been omitted, because they are not necessarily maximum limits of submergence in the areas. 
Richards Bay where altitudes exceed 900 feet. During emergence this island increased in area until, with the rising of the low divide separating Quilliam and Griffith bays it was joined to the mainland.

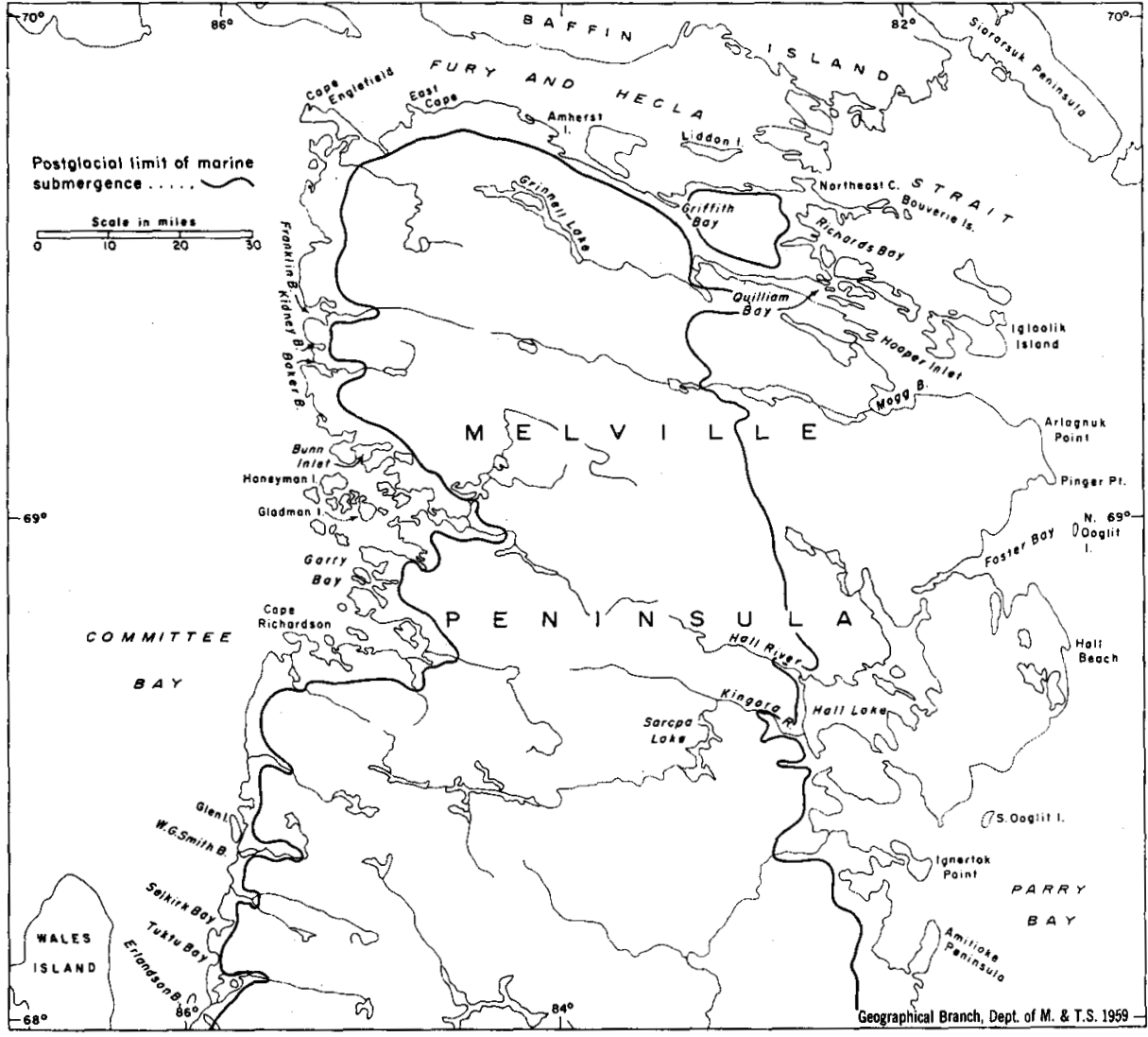

Fig. 8. Map showing the post-glacial limit of marine submergence.

With apparently only one exception the entire lowland on the east side of the peninsula from Amitioke Peninsula to Quilliam Bay was submerged. The sea covered the lower areas of Precambrian rock and penetrated into the valleys of many of the rivers draining east to Hall Lake and Foxe Basin. The steeply rising scarp that now forms the west coast of Hall Lake marked the shoreline at the marine maximum. This coast must have been similar in appearance to the present eastern shoreline of Foxe Basin between Wordie and Taverner Bays. In that area the Precambrian crystalline rocks rise gently from the shore in low knobs seldom exceeding 60 feet in altitude. Between Hall Lake and Quilliam Bay the coast appears to have been low and shelving. The only sedimentary area 
that may have escaped submergence is a small tract south of Quilliam Bay. Here, at an altitude exceeding 400 feet on a plateau bounded on the north and south by limestone scarps, east-west glacial fluting is visible on the air photographs of the area. Well-developed strand-lines are present as far as the base of the north facing scarp. Blackadar (1958, pp. 163-4) points out that it is improbable that such flutings would be so well preserved had the area been submerged and subjected to wave action. He suggests that areas such as this may have been covered by ice that protected it until the land had risen above seal-level. This agrees with the opinion expressed on page 190.

\section{References}

Bird, J. B. 1953. Southampton Island. Geographical Branch, Mem. 1, Ottawa: Queen's Printer, $84 \mathrm{pp}$.

1954. Postglacial marine submergence in central arctic Canada. Geol. Soc. Am. Bull. 65:457-64.

1955. Postglacial emergence of the land around Bathurst Inlet, Northwest Territories. Can. Geog. No. 6:7-12.

Blackadar, R. G. 1958. Patterns resulting from glacier movements north of Foxe Basin, N.W.T. Arctic 11:157-65.

Charlesworth, J. K. 1957. The Quaternary era, with special reference to its glaciation. London: Edward Arnold Ltd., 2 vols., 1700 pp.

Daley, R. A. 1902. Geology of the northeast coast of Labrador. Bull. Mus. Comp. Zool. Harvard Univ. 38: Geol. Ser. 5, pp. 205-270.

1934. The changing world of the Ice Age. New Haven: Yale Univ. Press,

$271 \mathrm{pp}$.

1938. Architecture of the earth. New York: Appleton-Century Co., 211 pp.

Flint, R. F. 1957. Glacial and Pleistocene geology. New York: Wiley and Sons, 553 pp.

Guilcher, A. 1958. Submarine and coastal geomorphology. London: Methuen Ltd., 274 pp.

Gutenberg, B. 1941. Changes in sea-level, post glacial uplift, and mobility of the earth's interior. Geol. Soc. Am. Bull. 52:721-772.

Loeblich, A. R. and H. Tappan, 1953. Studies of arctic foraminifera. Smithsonian Misc. Collect. 121 (7):1-142.

MacGinitie, G. E. 1955. Distribution and ecology of the marine invertebrates of Point Barrow, Alaska. Smithsonian Misc. Collect. 128 (9):1-201.

Mathiassen, T. 1933. Contributions to the geography of Baffin Land and Melville Peninsula. Fifth Thule Exped., 1921-24, Rept. Vol. 1, No. 3, 102 pp.

Mercer, J. H. 1954. The physiography and glaciology of southernmost Baffin Island. Ph.D. thes., McGill Univ., Montreal. 150 pp. Unpublished.

Thompson, H. R. 1954. Pangnirtung Pass, Baffin Island; an exploratory regional geomorphology. Ph.D. thes., McGill Univ., Montreal. 202 pp. Unpublished.

Washburn, A. L. 1947. Reconnaissance geology of portions of Victoria Island and adjacent regions of arctic Canada. Geol. Soc. Am. Mem. 22, 142 pp. 